\title{
Digital Citizenship Infrastructure to Foster the Reinforcement of National Identity in Indonesia
}

\section{KEYWORDS}

Citizenship Infrastructure, National Identity, Citizenship Education, Literacy

\begin{abstract}
Alif Aditya Candra, Karim Suryadi, Rahmat, Siti Nurbayani, Digital Citizenship Infrastructure to Foster the Reinforcement of National Identity in Indonesia. Culture - Society - Education no. 1(19) 2021, Poznań 2021, pp. 37-50, Adam Mickiewicz University Press. ISSN 2300-0422. DOI 10.14746/kse.2021.19.3
\end{abstract}

This study was to discuss and overview the infrastructure of digital citizenship in fostering the reinforcement of national identity in Indonesia. This study was prompted by a problem in the development of digital citizenship infrastructure, which could be an instrument in fostering national identity in Indonesia. The process of forming a national identity could be emphasized through various platforms in the digital citizenship infrastructure, so that the internalization of national values among Indonesian citizens could strengthen their identity as such. This study took the form of qualitative research with a phenomenological approach, constructing theories and phenomena concerning the infrastructure of digital citizenship in Indonesia. The results showed that the infrastructure of digital citizenship reinforced national identity in Indonesia in three ways, namely: 1) internalizing awareness of digital literacy through Citizenship Education learning, 2) implementing Habituation of national identity values in the digital citizenship infrastructure, and 3) running digital forums that could reinforce the digital citizenship infrastructure and strengthen national identity.

* ORCID https://orcid.org/0000-0002-1916-9952.

** ORCID https://orcid.org/0000-0002-3492-3175.

$* * *$ ORCID https://orcid.org/0000-0001-9261-3047.

**** ORCID https://orcid.org/0000-0002-4786-3124. 


\section{Introduction}

National identity as a value of the national character has experienced a crisis that has an impact on an identity crisis for every nation. Mukherjee (2018) states that the digital vision has facilitated the growth of a transparent governance infrastructure. In the same sense, Alinejad and Ponzanesi (2020) claim that there is a digitally mediated experience that shapes subjectivity. Therefore, the national character value in the digital scope will be influenced by the development of the digital infrastructure.

The rapid growth of information technology creates challenges and opportunities in terms of national identity. Treré et al. (2020) state that the availability of rapid internet access has connected people to their social networks as a daily experience. This can be seen from the fact that people are currently influenced by the internet. In this regard, Harvey and Ala-Fossi (2016) also argue that the commitment to internet convergence has affected communicative patterns and created new challenges in co-existing with the internet.

The digital citizenship infrastructure participates in fostering the national identity of a nation. Lechner (2007) says that the re-definition of national identity has varied across sectors as global pressure. When the phenomenon of global pressure is reviewed, a pattern of national identity will form itself with a number of indicators.

Fostering citizens' national identity through the digital citizenship infrastructure will follow the behavior of active citizens on digital platforms. A study by Gómez (2020) established that the economy is the basis of digital inequality and a barrier to material access. Meanwhile, Edensor (2004) clarifies that the discussion on nation and national identity tends to focus on the cultural elite of the authoritative culture, the traditions, and the customs of their people. Therefore, it is currently important to classify the national identity of citizens through the digital citizenship infrastructure.

The issue of digital citizenship infrastructure has recently been increasingly discussed and this has become a discussion in terms of culture and technological development, and aims to form good and civilized citizens in terms of digital citizenship infrastructure. It is necessary to pay attention to it in today's world. Moreover, the issue of national identity intersects with digital citizenship infrastructure, which can provide a new sense of national identity. Related to this matter, when identifying social psychological patterns of the narrative composition, the results can reflect some ideal features of national identity (László et al., 2003). Meanwhile, the emergence of new media and social change has become a concern in the realm 
of digital citizenship (Xu et al., 2018), because the construction of a national identity is a negotiation between a nation's Selbstbilds and their Fremdbilds (Rusciano, 1997). Therefore, regarding the digital citizenship infrastructure, it is necessary to rethink the 'digital' aspect of national identity.

From another perspective, Jones and Mitchell (2015) provide clarification that digital citizenship seeks to manifest and interpret online behavior and online civic engagement of society. Moreover, awareness is constitutional (Rosana, 2014). In this case, the infrastructure of digital citizenship will create a number of considerations in the construction of national identity in the digital era.

As a large and diverse country in terms of national identity, Indonesia certainly faces many obstacles. Based on Law Number 24 of 2009 concerning the Flag, Language, National Symbol, and National Song, they are positioned as national identity and the identity of the Unitary State of the Republic of Indonesia. However, in terms of national identity and digital citizenship infrastructure in the context of Indonesia, we find several fundamental problems, namely:

1. There is violence and mass upheaval as a form of vertical and horizontal tension due to it being a pluralistic society (Apud, n.d.);

2. It is necessary to formulate, define and review the concept of Indonesian national identity, as well as to measure Indonesian nationalism (Agung, 2017);

3. The advance of technology has the potential to shift Indonesian culture as well as the identity of Indonesians (Rayta, n.d.);

4. Globalization is a challenge for national identity (Syifa Syarifah A., Kusuma, 2015);

5. Formal education should be the product of Indonesian individual identities (Syifa Syarifah A., Kusuma, 2015).

Based on the phenomenon concerning national identity and digital citizenship infrastructure in the context of Indonesia, the problem is how an infrastructure for digital citizenship can foster the reinforcement of national identity in Indonesia. In fact, national identity characterizes a nation. Strengthening national identity is a required effort, because it is the nature of the integrity of nation and state (Rahayu, 2007). In this case, Tranter and Donoghue (2014) emphasize that the aspects of a nation's national narrative need to be studied. Therefore, in terms of national identity, a complete construction is fundamental to affirm the national identity as a nation.

With regard to previous problems, this study aims to identify the digital citizenship infrastructure that can foster the reinforcement of national identity in Indonesia. It is in line with Shelley et al's view (2004) that developing digital skills 
is positively related to digital citizenship. In one way, there is a problem in the development of digital citizenship infrastructure in observing national identity in Indonesia.

We believe that digital citizenship infrastructure can foster the reinforcement of national identity in Indonesia. National identity actually gives direction to citizens, and the framework of digital citizenship (in the perspective of sociology) concerns social cohesion with people's digital practices (Harris \& Johns, 2020). Therefore, it is appropriate for digital citizenship infrastructure to foster the reinforcement of national identity to create identity awareness for citizens, so that state workers are aware of their rights and obligations in the nation and state's life.

\section{Materials and Methods}

This study focused on the infrastructure of digital citizenship in fostering the reinforcement of national identity in Indonesia. This study took the form of descriptive qualitative research with a phenomenological approach, where it constructed theories and phenomena in the infrastructure of digital citizenship in Indonesia. Qualitative research is a research procedure that produces descriptive data in the form of written words (Moleong, 2007). In this study, data were collected through literature studies taken from various literature related to digital citizenship infrastructure in fostering the reinforcement of national identity.

This study was started by analyzing the phenomenon by using phenomenology perspective. Then, the author established the subject being studied, performed data collection, note-taking, analyzed data, and produced a written report. In the phenomenological process, this study referred to Alase's idea (2017) that phenomenology is a qualitative methodology that allows researchers to apply their subjectivity and interpersonal skills in exploratory research processes.

The final stage was data analysis, which was performed through several stages, namely (a) understanding the data as a whole, (b) compiling descriptions, (c) identifying, (d) applying themes, and (e) synthesizing explanations for each theme.

\section{Results and Discussion}

Any comments and suggestions are welcomed so that we can constantly improve this template to satisfy all authors' research needs. 


\subsection{The Internalization of Digital Awareness through Citizenship Education}

The awareness of digital meditation in terms of the digital citizenship infrastructure with the aim of fostering the reinforcement of national identity in Indonesia requires support as a medium for the success of the vision of digital citizenship infrastructure and national identity. In this case, educational facilities still become a superior means for the Indonesian in inheriting the noble values of the nation. Moreover, the Citizenship Education learning scheme, as stated in the state constitution Article 37 paragraph (1) and (2) Law No. 20 of 2003 concerning National Education System, confirms that Citizenship Education is compulsory in the curricula of primary education, secondary education and higher education.

Citizenship Education is useful as a subject that conveys the noble values of the nation. In this case, Levinson (2003) stated that Citizenship Education is the main goal of public schools and is beneficial in fostering an awareness of the state in its citizens. Meanwhile, the competencies that need to be developed in Citizenship Education are civic skills, civic disposition, and civic knowledge, and with the aim of reinforcing national identity and the digital citizenship infrastructure, Citizenship Education should become a vehicle for internalizing digital awareness through Citizenship Education (Branson, 1999). In this regard, we present a model for internalizing digital awareness through Citizenship Education.

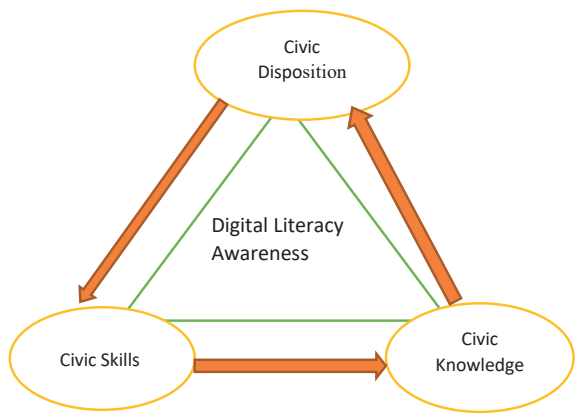

Figure 1. Internalization Model of Digital Meditation Awareness through Citizenship Education

Based on Figure 1, there is an expectation that the actions undertaken in Citizenship Education learning will have an effect on citizens' immediate actions. Wahab and Sapriya (2011) argue that the attitude of citizens will be effective only by fostering moral values in society. In the same sense, a study by Nurdin (2017) indicated that the development of topics in Citizenship Education is delegated to each university. Meanwhile, Ben-Porath (2007) states that patriotism should be 
considered as a part of citizenship that can contribute to future education policy makers. Therefore, in the internalization of digital awareness through Citizenship Education it is assumed that citizens' behaviour will produce an effective result through fostering moral values in Citizenship Education.

Furthermore, the internalization of digital awareness through Citizenship Education will be useful in strengthening citizenship identity in the digital citizenship infrastructure. It should be noted McCosker and Johns (2014) state that social media can be an example of digital awareness, which can allow a variety of creativity, cultural expression, public, and civic participation. However, unexpectedly, there are various consequences, particularly in citizenship identity.

To reconsider, digital awareness is necessary to foster, guide and direct the attitudes of citizens to digital media. Despite some developments in various international jurisdictions, there must still be policies and practices of educators, online communities and social media networks to fulfil the commitment of digital equal citizenship (Henry \& Powell, 2016). Moreover, when the internet provides various ways for discussion, internet-accessing skills need to be developed in anyone who uses the media (Beam et al., 2018).

It is undeniable that Citizenship Education is a means to build digital literacy awareness to realize national identity. In this regard, Sandu (2015) states that society is currently undergoing a process of progressive transformation of globalization space. Therefore, preparing active citizens is one of the main goals of higher education (Evans et al., 2018). Moreover, Citizenship Education cannot ignore any involvement in digital literacy to create competent citizens.

The benefits of digital literacy awareness can be gained by using social media as an educational medium for the community in delivering digital learning for the sake of society. Georgiou (2019) states that the digital order needs protection, and that security and privacy should underpin the experience of technology users in contemporary society (Norval, Prasopoulou, 2018). Therefore, an awareness of digital literacy is carried out as a prerequisite for strengthening digital citizenship infrastructure.

Digital literacy awareness in Citizenship Education is an important part of advancing participation in society. In this case, Menezes (2003) states that participation is considered as a crucial dimension of citizenship. In addition, Citizenship Education should provide education with a recommendation for policies and programs in the context of civic events (Purnell et al., 2016). Therefore, the awareness of digital literacy in Citizenship Education in Indonesia has become a civic experience that has opened up freedom and encouraged changes in several aspects of national life and the beginnings of the development of democracy in the context of Indonesia. 
The expansion of democracy in the awareness of digital literacy on Citizenship Education has made it successful in dealing with political transitions that occur in national life. Witschge and Werfhorst (2019) argue that civic and political involvement are linked to participation in higher education. Meanwhile, understanding the geographic dimensions of citizenship can foster democracy through contemporary digital activism (Baek, 2018). Therefore, the awareness of digital literacy in Citizenship Education will enable individuals to take part in civilian life.

\subsection{The Habituation of National Identity Values in the Digital Citizenship Infrastructure}

The values of national identity in digital citizenship infrastructure need to be introduced to society through various means. Dougherty (2018) claims that the concept of development reflects a collection of individual values and maps to societal attitudes. Furthermore, it is possible to effect a dramatic change by showing the level of prejudice (Durrheim et al., 2011). Therefore, the customization of national identity values in a digital citizenship infrastructure requires a method that can be embedded in citizens; not only knowledge itself.

In the Indonesian context, the inculcation of national identity values in the digital citizenship infrastructure is reflected in the form of communicating on social media, which should still use Indonesian traditions. This means that in digital activity, citizens must still uphold the values of nation and state. In this case, Lau (2014) argued that this type of political discourse will be of benefit in reviving the political imagination of society. Therefore, the habituation of national identity values needs to be realized and used as a manifestation of digital citizenship infrastructure in Indonesia. The following figure shows a model of habituation of the values of national identity in the digital citizenship infrastructure:

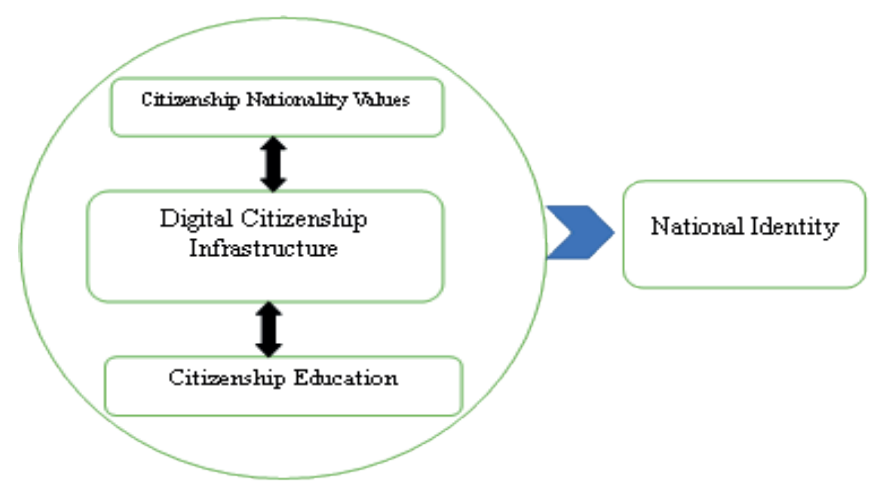

Figure 2. The Habituation Model of National Identity Values in Digital Citizenship Infrastructure 
The figure gives an indication that in practical terms, a citizenship infrastructure which is often considered inappropriate in national identity schemes has commonly led to strengthen national identity. Chow and Kennedy (2015) argue that there are a number of variations in civic engagement among young citizens. Meanwhile, the study by Miranda et al. (2017) found that a conceptual model that includes a community dimension and civic dimension was proposed in all countries, so that the habituation of national identity values in digital citizenship infrastructure becomes an important aspect in the study of national identity.

The habituation of national identity values is still minimum and should be taken into account in the Indonesian context. This phenomenon is indicated by the presence of passive community participation in which media plays an important role in informing young people about politics. The results of a study on debate programs on television and how they influence the normative democratic attitudes of young citizens also reveal that debates bolster the effectiveness of political information for young citizens. Therefore, familiarizing values of national identity can increase community participation carried out by citizens.

The values of national identity are considered capable of overcoming the problem of moral degradation in a nation, because the movement of national identity increasingly characterizes the attitude of citizens. Cammaerts et al. (2013) state that a low level of voter participation among young people does not mean that they are a selfish generation. In line with this, a longitudinal study by McKinney et al. (2013) on the democratic attitudes of young citizens found that the effectiveness of political information can be increased by campaigns. However, the values of national identity that are adopted will be able to form a complete character of citizens.

The habituation of national identity values in the digital citizenship infrastructure will strengthen this digital citizenship infrastructure. The results of a study by Shelley et al. (2004) emphasize that some attitudes towards technology have a direct impact on digital citizens. Moreover, a rights-based approach to digital media offers a framework for balancing online protection (Livingstone, Third, 2017). Therefore, the value of national identity in the digital citizenship infrastructure scheme is a new means for positioning citizens for affirming national identity.

\subsection{A Digital Forum that Can Strengthen Digital Citizenship Infrastructure and National Identity}

Without digital forums, digital citizenship infrastructure for reinforcing national identity will not materialize (Pegrum, 2010), and this is common sense in today's world. Alinejad and Ponzanesi (2020) state that emotions can have a comprehen- 
sive impact on digital mediation in social life. Therefore, the digital citizenship infrastructure has become one of the means of reinforcing national identity.

In the context of Indonesia, digital forums in the digital citizenship infrastructure to reinforce national identity are an instrument that contributes to globally focused relations.

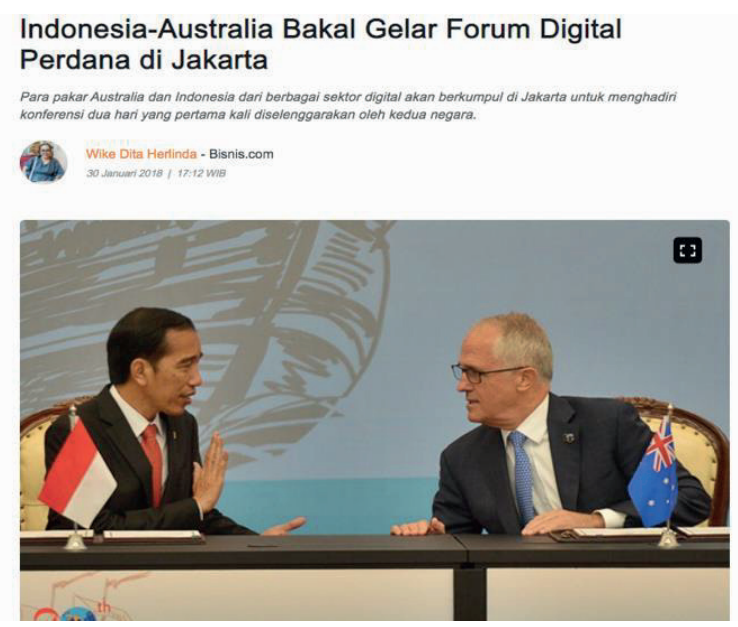

Figure 3. President Joko Widodo in his Meeting with the Australian Prime Minister Malcolm Turnbull at the Signing of the Jakarta Concord at the 2017 Indian Ocean Rim Association (IORA) Summit

The existence of a digital forum allows Indonesians to show their existence as a nation. We therefore need a sufficient spectrum in terms of conveying information and cultural assets (Harvey \& Ala-Fossi, 2016). Furthermore, in social science analysis, the digital gap allows the majority of people to strengthen their ability to survive (Mansell, 2002). In line with this, Kuntsman and Miyake (2019) state that the concept of 'digital disengagement' has a number of implications for the relationship between digital media, culture and society. Therefore, the existence of a digital forum is important for reinforcing the identity of nation.

The digital forum is a vehicle (media) to reinforce national identity, because it can minimize any passive attitude of the community in state civil affairs. Hidayah et al. (2020) argue that civil society intelligence is put into action. Moreover, building this intelligence among citizens requires the media (Candra \& Suryadi, 2020), so digital forums will be an important channel through which to inform the public about their rights and obligations as citizens.

Martini et al. (2018) state that technology leads to the intelligence of citizens, because digital forums are one of the products of globalization. In contrast, com- 
munication and expression are limited by a new digital system (Plantin et al., 2016), so that the challenges and limitations of digital participatory practice should be overcome through an alternative participant-centered approach (Pawluczuk et al., 2018). Thus, in terms of reinforcing Indonesians' national identity through digital forums, many reactions and results will emerge.

Based on a reality this, Indonesia is still far from an ideal atmosphere in terms of reinforcing national identity due to the lack of public participation, facilities, and literacy awareness. Van Doorn (2019) states that by mobilizing its user-base, a community can get many opportunities through technology support. On the other hand, the discourse of pragmatic practices of social rights, political citizenship, and common good will have been adopted by citizens themselves (Cardullo \& Kitchin, 2018). In this respect, the ideal atmosphere for reinforcing national identity will continue to develop.

The path taken by Indonesians to achieve an ideal climate for reinforcing national identity through the digital citizenship infrastructure will affect the attitudes of integrity, as evidenced by factual data, because in future, Indonesia will need people who can foster this development (Darmawan, 2015). By this, in the dimension of digital citizenship infrastructure, society will experience a number of dynamics during Indonesia's political growth. Moreover, by the voice of the government is the dream of all countries which can support the public's aspirations (Darmawan, 2015).

Strictly speaking, in the scope of digital citizenship infrastructure in Indonesia, (in many respects) public participation will increase. Digital practice will encourage identity management (Udwan et al., 2020), while Irani (2015) states that this commitment is in line with the political and social system, and that mass democracy is constructed in coalitions across variety of differences. Therefore, the infrastructure scope for digital citizenship in Indonesia will constitute a means of developing, expanding and constructing a digital citizenship infrastructure and national identity.

\section{Conclusion}

Digital citizenship infrastructure for fostering the reinforcement of national identity in Indonesia is in line with the development of digital citizenship infrastructure instruments in observing national identity. The view of the digital citizenship infrastructure shows that in its implementation in the life of the nation, it still provides the noble values of the nation as a historical legacy. However, internal- 
izing digital awareness through Citizenship Education learning is a process in the formation of national identity in Indonesia, which can be emphasized through various platforms in the digital citizenship infrastructure, so that the internalization of national values for Indonesian will be able to strengthen their character.

The habituation of national identity values in the digital citizenship infrastructure will be in line with the inhabiting national identity values that can be applied in society and the digital environment. Moreover, digital forums can reinforce the infrastructure of digital citizenship and national identity to produce individuals of good, intelligent and wise character in performing digital activities.

\section{Acknowledgements}

Alif Aditya Candra is a doctoral student in the Department of Citizenship Education, Indonesia University of Education. This article is a part of his dissertation research that has been carried out to obtain a doctoral degree in the field of Citizenship Education.

\section{Bibliography}

Agung D. (2017), Memperkokoh Identitas Nasional Untuk Meningkatkan Nasionalisme, Jakarta.

Alase A. (2017), The Interpretative Phenomenological Analysis (IPA): A Guide to a Good Qualitative.

Alinejad D., Ponzanesi S. (2020), Migrancy and Digital Mediations of Emotion, International Journal of Cultural Studies, 23(5).

Apud M. (n.d.), "Plural Society" dan Konflik Identitas, http://www.detiknews.com, accessed: 17.12.2020.

Baek K. (2018), The Geographic Dimension of Citizenship in Digital Activism: Analysis of The Relationships Among Local and Global Citizenship, The Use of Social Networking Sites, and Participation in The Occupy Movement, American Behavioral Scientist, 62(8).

Beam M.A., Hmielowski J.D., Hutchens M.J. (2018), Democratic Digital Inequalities: Threat and Opportunity in Online Citizenship From Motivation and Ability, American Behavioral Scientist, 62(8).

Ben-Porath, S. (2007), Civic Virtue Out of Necessity: Patriotism and Democratic Education, Theory and Research in Education, 5(1).

Branson M.S. (1999), Belajar Civic Education dari Amerika, Yogyakarta.

Cammaerts B., Bruter M., Banaji S., Harrison S., Anstead N. (2013), The Myth of Youth Apathy: Young Europeans' Critical Attitudes Toward Democratic Life, American Behavioral Scientist, 58(5).

Candra A.A., Suryadi K. (2020), Building A Digital Intelligence on Millennial Generation Through Strengthening National Identity, Journal of Physics: Conference Series, 1469(12098). 
Cardullo P., Kitchin R. (2018), Smart Urbanism and Smart Citizenship: The Neoliberal Logic of 'Citizen-Focused' Smart Cities in Europe, Environment and Planning C: Politics and Space.

Chow J.K.F., Kennedy K.J. (2015), Asian Students' Conceptions of Future Civic Engagement: Comparing Clusters Using Person-Centered Analysis, Research in Comparative and International Education, 10(1).

Darmawan C. (2015). Legislative Strengthening and Empowerment: Efforts To Strengthen Local Governance and Accountability Through Provincial Parliaments in Indonesia, American Journal of Applied Sciences, 12.

Doorn N. van (2019), A New Institution on The Block: on Platform Urbanism and Airbnb Citizenship, New Media \& Society, 22(10).

Dougherty M.L. (2018), How Does Development Mean? Attitudes Toward Mining and The Social Meaning of Development in Guatemala, Latin American Perspectives, 46(2).

Durrheim K., Tredoux C., Foster D., Dixon J. (2011), Historical Trends in South African Race Attitudes, South African Journal of Psychology, 41(3).

Edensor T. (2004), Automobility and National Identity: Representation, Geography and Driving Practice, Theory, Culture \& Society, 21(4-5).

Evans B.J., Marsicano C.R., Lennartz C.J. (2018), Cracks in The Bedrock of American Democracy: Differences in Civic Engagement Across Institutions of Higher Education, Educational Researcher, $48(1)$.

Georgiou M. (2019), City of Refuge or Digital Order? Refugee Recognition and The Digital Governmentality of Migration in The City, Television \& New Media, 20(6).

Gómez D.C. (2020), The Third Digital Divide and Bourdieu: Bidirectional Conversion of Economic, Cultural, and Social Capital to (and from) Digital Capital Among Young People in Madrid, New Media \& Society.

Harris A., Johns A. (2020), Youth, Social Cohesion and Digital Life: From Risk and Resilience to a Global Digital Citizenship Approach, Journal of Sociology.

Harvey S., Ala-Fossi M. (2016), Eroding The Assets of Citizenship? From Broadcast To Broadband, International Communication Gazette, 78(4).

Henry N., Powell A. (2016), Sexual Violence in The Digital Age: The Scope and Limits of Criminal Law, Social \& Legal Studies, 25(4).

Herlinda W.D. (n.d.), Indonesia-Australia Bakal Gelar Forum Digital Perdana Di Jakarta, http://www. kabar24.com, accessed: 17.12.2020.

Hidayah Y., Sapriya, Darmawan C., Malihah E., Karliani E. (2020), Promoting Civic Intelligence in Applied Science to Promote Interaction Between Science: An Overview in the Perspective of Citizenship Education, Universal Journal of Educational Research.

Irani L. (2015), Hackathons and the Making of Entrepreneurial Citizenship, Science, Technology, \& Human Values, 40(5).

Jones L.M., Mitchell K.J. (2015), Defining and Measuring Youth Digital Citizenship, New Media \& Society, 18(9).

Kuntsman A., Miyake E. (2019), The Paradox and Continuum of Digital Disengagement: Denaturalising Digital Sociality and Technological Connectivity, Media, Culture \& Society, 41(6).

László J., Vincze O., Somogyvári I.K. (2003), Representation of National Identity in Successful Historical Novels, Empirical Studies of the Arts, 21(1).

Lau A. (2014), Intimating The Unconscious: A Psychoanalytical Refraction of Christian Theo-Political Activism in Malaysia, Critical Research on Religion, 2(3). 
Lechner F.J. (2007), Redefining National Identity: Dutch Evidence on Global Patterns, International Journal of Comparative Sociology, 48(4).

Levinson M. (2003), Challenging Deliberation, Theory and Research in Education, 1(1): 23-49.

Livingstone S., Third A. (2017), Children and Young People's Rights in the Digital Age: An Emerging Agenda, New Media \& Society, 19(5).

Malihah E. (2015), An Ideal Indonesian in an Increasingly Competitive World: Personal Character and Values Required to Realise a Projected 2045 'Golden Indonesia', Citizenship, Social \& Economics Education, 14(2).

Mansell R. (2002), From Digital Divides to Digital Entitlements in Knowledge Societies, Current Sociology, 50(3).

Martini E., Trihastuti M., Candra A.A. (2018), Understanding of Human Rights through Civic Education in The $21^{\text {st }}$ Century, [in:] Annual Civic Education Conference (ACEC 2018), Advances in Social Science, Education and Humanities Research, vol. 251.

McCosker A., Johns A. (2014), Contested Publics: Racist Rants, Bystander Action and Social Media Acts of Citizenship, Media International Australia, 151(1).

McKinney M.S., Rill L.A., Thorson E. (2013), Civic Engagement Through Presidential Debates: Young Citizens' Political Attitudes in The 2012 Election, American Behavioral Scientist.

Menezes I. (2003), Participation Experiences and Civic Concepts, Attitudes and Engagement: Implications For Citizenship Education Projects, European Educational Research Journal, 2(3).

Miranda D., Castillo J.C., Sandoval-Hernandez A. (2017), Young Citizens Participation: Empirical Testing of A Conceptual Model, Youth \& Society, 52(2).

Moeller J., Vreese C. de, Esser E., Kunz R. (2013), Pathway To Political Participation: The Influence of Online and Offline News Media on Internal Efficacy and Turnout of First-Time Voters, American Behavioral Scientist, 58(5).

Moleong L.J. (2007), Metodologi Penelitian Kualitatif, Bandung.

Mukherjee R. (2018), Jio Sparks Disruption 2.0: Infrastructural Imaginaries and Platform Ecosystems in 'Digital India', Media, Culture \& Society, 41(2).

Norval A., Prasopoulou E. (2018), Seeing Like A Citizen: Exploring Public Views of Biometrics, Political Studies, 67(2).

Nurdin E.S. (2017), Civic Education Policies: Their Effect on University Students' Spirit of Nationalism and Patriotism, Citizenship, Social and Economics Education, 16(1).

Pawluczuk A., Hall H., Webster G., Smith C. (2018), Youth Digital Participation: Measuring Social Impact, Journal of Librarianship and Information Science, 52(1).

Pegrum M. (2010), 'I Link, Therefore I Am’: Network Literacy as a Core Digital Literacy, E-Learning and Digital Media, 7(4).

Plantin J.-C., Lagoze C., Edwards P.N., Sandvig C. (2016), Infrastructure Studies Meet Platform Studies in The Age of Google and Facebook, New Media \& Society, 20(1).

Purnell J.Q., Goodman M., Tate W.F., Harris K.M., Hudson D.L. et al. (2016), For The Sake of All: Civic Education on The Social Determinants of Health and Health Disparities in St. Louis, Urban Education, 53(6).

Rahayu M. (2007), Pendidikan Kewarganegaraan Perjuangan Menghidupi Jati Diri Bangsa, Depok.

Rayta A. (n.d.), Pengaruh Teknologi Terhadap Identitas Bangsa Indonesia, http://www.kumparan. com, accessed: 17.12.2020.

Rosana E. (2014), Kepatuhan Hukum Sebagai Wujud Kesadaran Hukum Masyarakat, Jurnal Tapis, $10(1)$. 
Rusciano F.L., Fiske-Rusciano R., Wang M. (1997), The Impact of 'World Opinion' on National Identity, Harvard International Journal of Press/Politics.

Sandu O.N. (2015), Civic and Intercultural Education: A Means For Community Development and Attitude Change, SAGE Open, 5(2).

Shelley M., Thrane L., Shulman S., Lang E., Beisser S. et al. (2004), Digital Citizenship: Parameters of The Digital Divide, Social Science Computer Review, 22(2).

Syifa Syarifah A., Kusuma, A. (2015), Globalisasi Sebagai Tantangan Identitas Nasional Bagi Mahasiwa Surabaya, Global \& Policy, 4(2), pp. 61-72.

Tranter B., Donoghue J. (2014), National Identity and Important Australians, Journal of Sociology, $51(2)$.

Treré E., Natale S. Keightley E., Punathambekar A. (2020), The Limits and Boundaries of Digital Disconnection, Media, Culture \& Society, 42(4).

Udwan G., Leurs K., Alencar A. (2020), Digital Resilience Tactics of Syrian Refugees in The Netherlands: Social Media For Social Support, Health, and Identity, Social Media + Society, 6(2).

Wahab A.A., Sapriya (2011), Teori dan Landasan Pendidikan Kewarganegaraan, Bandung.

Witschge J., Werfhorst H.G. van de (2019), Curricular Tracking and Civic and Political Engagement: Comparing Adolescents and Young Adults Across Education Systems, Acta Sociologica, 63(3).

Xu S., Yang H.H., Macleod J., Zhu S. (2018), Social Media Competence and Digital Citizenship Among College Students, Convergence, 25(4). 